\title{
Pengembangan Buku Ajar Matematika Berbasis Matematika Terapan Pada Materi Trigonometri untuk Peserta Didik SMK Kelas X
}

\author{
Miftahul Jannah Anri ${ }^{1}$, Joko Soebagyo ${ }^{2}$ \\ ${ }^{1,2}$ Prodi Pendidikan Matematika, Fakultas Keguruan dan Ilmu Pendidikan, Universitas Muhammadiyah Prof. Dr. HAMKA, \\ Jl. Tanah Merdeka No 20, Jakarta Timur, Indonesia \\ Miftahanri16@gmail.com
}

\begin{abstract}
This study aims to develop a mathematics textbook based on applied mathematics on Trigonometry material. The method used in this study is the research and development method (Research \& Development) with the ADDIE development model which goes through several stages, namely Analysis, Design, Development, Implementation, and Evaluation to get a feasible and effective product and can be used in learning. The data collection technique in this study was to conduct interviews and use questionnaires to 2 material experts and 2 media experts to test the feasibility of textbooks, then a small-scale trial questionnaire was given to 4 students of class X Teknik Kendaraan Ringan (TKR) at SMKN 39 Jakarta and carried out a large-scale trial to 68 students of class X Teknik Kendaraan Ringan (TKR) at SMKN 39 Jakarta. Based on the results of the study, textbooks based on applied mathematics on Trigonometry material obtained an assessment of very good criteria with a percentage of $92.5 \%$ from material experts and $86.5 \%$ from media experts. The results of the small-scale trials were categorized as very good with a percentage of $85.5 \%$ and $83 \%$ with very good categories during large-scale trials. So, it can be concluded that mathematics textbooks based on applied mathematics on trigonometry material are feasible and effective for students of SMK Negeri 39 Jakarta.
\end{abstract}

Keywords: Mathematics, Textbooks, Applied Mathematics, ADDIE, Trigonometry

\begin{abstract}
Abstrak
Penelitian ini bertujuan untuk mengembangkan buku ajar matematika berbasis matematika terapan pada materi Trigonometri. Metode yang digunakan dalam penelitian ini yaitu metode penelitian dan pengembangan (Research \& Development) dengan model pengembangan ADDIE yang melalui beberapa tahap yaitu Analisis, Perancangan, Pengembangan, Implementasi, dan Evaluasi untuk mendapatkan produk layak dan efektif serta dapat digunakan dalam pembelajaran. Teknik pengumpulan data pada penelitian ini ialah melakukan wawancara dan menggunakan angket kepada 2 orang ahli materi dan 2 orang ahli media untuk menguji kelayakan buku ajar, kemudian angket uji coba skala kecil diberikan kepada 4 peserta didik kelas X Teknik Kendaraan Ringan (TKR) SMKN 39 Jakarta, serta dilakukan uji coba skala besar kepada 68 peserta didik kelas X Teknik Kendaraan Ringan (TKR) SMKN 39 Jakarta. Berdasarkan hasil penelitian, buku ajar berbasis matematika terapan pada materi Trigonometri memperoleh penilaian berkriteria sangat baik dengan persentase $92,5 \%$ dari ahli materi dan $86,5 \%$ dari ahli media. Hasil uji coba skala kecil memperoleh penilaian berkategori sangat baik dengan persentase $85,5 \%$ dan $83 \%$ dengan berkategori sangat baik saat uji coba skala besar. Sehingga dapat disimpulkan bahwa buku ajar matematika berbasis matematika terapan pada materi Trigonometri layak dan efektif digunakan peserta didik SMK Negeri 39 Jakarta.
\end{abstract}

Kata kunci: Matematika, Buku Ajar, Matematika Terapan, ADDIE, Trigonometri

Copyright (c) 2021 Miftahul Jannah Anri, Joko Soebagyo

Corresponding author: Joko Soebagyo

Email Address: joko_soebagyo@uhamka.ac.id (Jl. Tanah Merdeka No.20, Jakarta Timur, Indonesia)

Received 16 July 2021, Accepted 10 August 2021, Published 11 August 2021

\section{PENDAHULUAN}

Pendidikan merupakan upaya yang bertujuan membantu peserta didik berkembang menuju peradaban manusia yang lebih baik lagi (Sujana, 2019). Pendidikan juga merupakan sarana untuk mencapai tujuan pertumbuhan dan perkembangan negara (Akbar \& Komarudin, 2018). Dalam pendidikan, matematika adalah salah satu pelajaran yang memiliki peran penting. Matematika adalah ilmu yang mempelajari mengenai bilangan, model, dan struktur yang terorganisasi (Nur'aini et al., 2017). Matematika merupakan salah satu disiplin ilmu yang terpenting dan memiliki peran strategis dalam perkembangan Ilmu 
Pengetahuan dan Teknologi (IPTEK), mengingat peran matematika yang begitu penting, upaya perbaikan sistem pembelajaran matematika selalu menjadi perhatian masyarakat, khususnya bagi pakar pendidikan matematika dan pemerintah. Sehingga mata pelajaran matematika diberikan kepada seluruh jenjang pendidikan formal mulai dari dasar hingga menengah. Sekolah Menengah Kejuruan (SMK) merupakan salah satu bentuk satuan pendidikan menengah formal yang mempersiapkan peserta didik terutama untuk bekerja dalam bidang tertentu. Bidang tertentu yang dimaksud adalah bidang yang dipilih dan dipelajari oleh peserta didik selama berada disatuan pendidikan tersebut. Pada Sekolah Menengah Kejuruan (SMK) seringkali mementingkan kegiatan praktik dibandingkan dengan teori, Sedangkan di Sekolah Menengah Atas (SMA) teori lebih penting daripada praktik. Dilihat dari kegiatan pembelajaran khususnya pada pembelajaran matematika di Sekolah Menengah Kejuruan (SMK) pasti akan berbeda dengan Sekolah Menengah Atas (SMA), karena kebutuhannya yang berbeda juga.

Pembelajaran matematika di Sekolah Menengah Kejuruan (SMK) khususnya kelompok teknologi dan rekayasa berdasarkan Permendikbud No.16 tahun 2007 dan Pendirjen 464/D.D5/KR/2018 masih bersifat umum dan teoritis. Sementara itu pembelajaran matematika Sekolah Menengah Kejuruan (SMK) kelompok teknologi dan rekayasa, idealnya, pembelajaran matematika seharusnya memadukan kapabilitas jurusan dan menunjang pengetahuan tentang matematika terapan, yang meliputi aspek keluasan, kedalaman, relevansi, dan keberlanjutan (Hine, 2015). Sebagai ilustrasi pembelajaran matematika Sekolah Menengah Kejuruan (SMK) pada jurusan Teknik Kendaraan Ringan (TKR), idealnya adalah menghubungkan ilmu matematika dan ilmu Teknik Kendaraan Ringan (TKR), agar proses pembelajaran menjadi lebih kontekstual dan mudah dipahami.

Untuk menciptakan pembelajaran menjadi kontekstual dan mudah dipahami dibutuhkan konten materi ajar matematika yang beririsan dengan bidang keahlian peserta didik. Menurut (Hassani, 2009) menyatakan cara terbaik untuk mengajarkan matematika kepada peserta didik adalah dengan memperkenalkan dan menggunakan konsep matematika diberbagai bidang. Ketersediannya buku ajar matematika berbasis matematika terapan untuk pembelajaran di Sekolah Menengah Kejuruan (SMK) khususnya kelompok teknologi dan rekayasa masih terbilang belum cukup tersedia dengan baik. Hasil observasi awal terhadap Buku Sekolah Elektronik (BSE) matematika Sekolah Menengah Kejuruan (SMK) kelompok teknologi dan rekayasa belum menunjukkan buku ajar yang mencakup matematika terapan di dalamnya. Untuk itu, diharapkan buku ajar yang tersedia lebih banyak menghubungkan pengetahuan untuk dapat diterapkan pada dunia praktik (Ojose, 2011). Buku ajar untuk mempermudah guru saat mengajar peserta didik dan saat guru mengalami kesulitan dalam proses pembelajaran. Tetapi kenyataannya buku ajar yang digunakan di Sekolah Menengah Kejuruan (SMK) masih belum membantu peserta didik dalam memahami konsep pada pembelajaran matematika, khususnya konsep pada materi Trigonometri.

Berdasarkan hasil penelitian relevan yang menjadi rujukan untuk pemilihan materi dalam buku ajar yang dikembangkan ini yaitu yang pertama, pada penelitian yang dilakukan oleh Tommy Tanu Wijaya, dkk., International Journal of Emerging Technologies in Learning (2020) dengan judul penelitian "Using Hawgent Dynamic Mathematics Software in Teaching Trigonometry". Dalam penelitian tersebut 
menyatakan bahwa Trigonometri merupakan salah satu mata pelajaran matematika yang dianggap sukit untuk dipelajari (Bernard et al., 2019). Peserta didik mengalami kesulitan pada menentukan sudut dan membuktikan identitas trigonometri (Wijaya, Ying, \& Purnama, 2020). Kedua, pada penelitian yang dilakukan oleh Zhou Ying, dkk., Journal on Education (2020) dengan judul “Using VBA Learning Media To Improve Students' Mathematical Understanding Ability". Dalam penelitian tersebut berdasarkan peneltiian lapangan, banyak peserta didik saat mempelajari Trigonometri hanya dengan menghafal rumus yang mengakibatkan peserta didik tersebut tidak mampu menerapkan konsep Trigonometri dalam kehidupan sehari-hari (Wijaya, Ying, \& Cunhua, 2020). Ketiga penelitian yang dilakukan oleh Vina Novianti, dkk., Jurnal Pembelajaran Matematika Inovatif (2021) dengan judul "Analisis Kesulitan Siswa SMK Dalam Menyelesaikan Soal Materi Trigonometri”. Hasil penelitian tersebut menunjukkan ada beberapa kesulitan yang dialami oleh peserta didik Sekolah Menengah Kejuruan (SMK) saat menyelesaikan soal Trigonometri, yaitu 1) Peserta didik tidak terbiasa menulis apa yang diketahui dan dipertanyakan saat memahami suatu masalah dalam menyelesaikan soal, 2) Peserta didik tidak terbiasa untuk menuliskan hasil akhir pada soal walaupun hasil yang ditemukannya itu benar, 3) Kurangnya pemahaman peserta didik dengan suatu konsep terhadap materi Trigonometri.

Dari penelitian diatas, maka peneliti memilih materi Trigonometri, karena terbilang sulit terlebih jika peserta didik dalam proses pembelajaran hanya sebatas mengahafal rumus yang mengakibatkan peserta didik tidak mampu menerapkan konsep Trigonometri pada kehidupan sehari-hari, kemudian saat peserta didik menyelesaikan soal Trigonometri peserta didik terbiasa tidak menulis yang diketahui dan dipertanyakan dalam soal, tidak terbiasa menuliskan hasil akhir pada soal yang ditanyakan. Berdasarkan penjelasan tersebut, peneliti mencoba untuk mengerjakan pengkajian dengan judul "Pengembangan Buku Ajar Matematika Berbasis Matematika Terapan Pada Materi Trigonometri Untuk SMK Kelas X".

\section{METODE}

\section{Lokasi dan Subjek Penelitian}

Penelitian ini dilaksanakan di SMK Negeri 39 Jakarta. Subjek penelitian ini meliputi para ahli sebagai validator buku ajar matematika berbasis matematika terapan, yang terdiri dari satu dosen matematika dan satu guru matematika untuk ahli materi serta satu dosen matematika dan satu guru bidang keahlian Teknik Kendaraan Ringan (TKR) untuk ahli media. Selain itu, dalam pengujian buku ajar matematika berbasis matematika terapan subjek penelitian ini melibatkan peserta didik SMK Negeri 39 Jakarta kelas X bidang keahlian Teknik Kendaraan Ringan (TKR) sebanyak 68 peserta didik dan guru matematika.

\section{Metode dan Prosedur Penelitian}

Jenis penelitian ini merupakan penelitian Research and Development (R\&D) dengan merujuk pada model ADDIE. Penulis memilih model ADDIE ini karena langkah-langkah yang disusun secara sistematis. Ini sejalan menurut (Tegeh et al., 2014). Model ADDIE merupakan model yang mudah dipahami dan dipelajari karena tahap-tahap yang saling berkaitan dan urutan kegiatan disusun secara sistematis untuk 
menyelesaikan masalah pembelajaran terkait sumber belajar, sehingga sesuai dengan kebutuhan dan karakteristik pembelajaran. Model ini terdiri dari lima tahap, yaitu Analysis (Analisis), Design (Perancangan), Development (Pengembangan), Implementation (Implementasi), Evaluation (Evaluasi). Dalam proses penelitian dan pengembangan ini dilakukan dengan lima tahapan, yaitu Analysis, Design, Development, Implementation, dan Evaluation. Deskripsi tahapan disajikan pada Tabel 1.

Tabel 1. Tahapan Model Pengembangan Analysis, Design, Development, Implementation, dan Evaluation (ADDIE)

\begin{tabular}{|l|l|l|}
\hline No & \multicolumn{1}{|c|}{ Tahapan } & \multicolumn{1}{c|}{ Deskripsi } \\
\hline 1 & Analysis & $\begin{array}{l}\text { Kegiatan ini untuk menentukan kebutuhan dalam kegiatan pembelajaran } \\
\text { dengan mengumpulkan berbagai informasi yang berhubungan dengan } \\
\text { buku ajar, meliputi analisis awal, analisis guru, dan analisis peserta didik. }\end{array}$ \\
\hline 2 & Design & $\begin{array}{l}\text { Kegiatan ini membuat rancangan buku ajar matematika yang akan } \\
\text { dikembangkan. Kegiatan ini meliputi menentukan Kompetensi Dasar } \\
\text { (KD), memperhatikan struktur buku ajar, penyajian materi, format yang } \\
\text { sesuai, dan membuat desain buku ajar. }\end{array}$ \\
\hline 3 & Development & $\begin{array}{l}\text { Kegiatan ini membuat dan memproduksi buku ajar matematika berbasis } \\
\text { matematika terapan, yang kemudian dilakukan uji validasi oleh ahli } \\
\text { materi dan ahli media serta dilanjutkan dengan penyempurnaan buku ajar. }\end{array}$ \\
\hline 4 & Impelementation & $\begin{array}{l}\text { Kegiatan ini dilakukan setelah buku ajar dinyatakan layak uji oleh para } \\
\text { ahli. Jika layak, buku ajar dapat diujicobakan kepada guru dan peserta } \\
\text { didik. }\end{array}$ \\
\hline 5 & Evaluation & $\begin{array}{l}\text { Kegiatan ini menyempurnakan buku ajar matematika berbasis matematika } \\
\text { terapan berdasarkan komentar dan saran dari para ahli, dan peserta didik } \\
\text { pada uji coba skala kecil. }\end{array}$ \\
\hline
\end{tabular}

Pada penelitian ini, instrumen validasi ahli, instrumen respon guru, serta instrumen respon peserta didik menggunakan skala likert. Dalam penelitian dan pengembangan, skala likert digunakan untuk mengukur sikap, persepsi, dan pendapat seseorang terhadap suatu produk yang dikembangkan (Sugiyono, 2019) Aturan pemberian skor pada instrumen tersebut yaitu pada Tabel 2.

Tabel 2. Aturan Penskoran Skala Likert

\begin{tabular}{|c|c|c|}
\hline No & Kategori & Skor \\
\hline 1 & Sangat Baik & 5 \\
\hline 2 & Baik & 4 \\
\hline 3 & Kurang Baik & 3 \\
\hline 4 & Tidak Baik & 2 \\
\hline 5 & $\begin{array}{c}\text { Sangat Tidak } \\
\text { Baik }\end{array}$ & 1 \\
\hline
\end{tabular}

Data kelayakan buku ajar matematika berbasis matematika terapan ini berupa deskriptif persentase. Data yang diperoleh dari para ahli, guru, serta peserta didik kemudian dihitung yaitu dengan menggunakan rumus sebagai berikut (Amirullah \& Susilo, 2018)

$$
P=\frac{f}{N} \times 100 \%
$$

Keterangan : 
$f=$ Frekuensi yang sedang dicari persentase-nya

$N=$ Number of Cases (Jumlah frekuensi / banyaknya individu)

$P=$ Angka persentase

Untuk persentase hasil penelitian, maka digunakan kriteria penilaian yang merupakan hasil konversi data kuantitatif menjadi data kualitatif menggunakan teori Sukardjo (Arif Z \& Abdillah, 2018) pada Tabel 3.

Tabel 3. Rentang Persentase dan Kategori Kelayakan Buku Ajar

\begin{tabular}{|c|l|}
\hline Rentang Persentase & Kriteria Penelitian \\
\hline $81 \%-100 \%$ & Sangat Baik \\
\hline $61 \%-80 \%$ & Baik \\
\hline $41 \%-60 \%$ & Kurang Baik \\
\hline $21 \%-40 \%$ & Tidak Baik \\
\hline $0 \%-20 \%$ & Sangat Tidak Baik \\
\hline
\end{tabular}

(Amirullah \& Susilo, 2018)

\section{HASIL DAN DISKUSI}

Penelitian dan pengembangan ini menghasilkan buku ajar matematika berbasis matematika terapan yang telah divalidasi dan di ujicobakan kepada guru matematika dan peserta didik SMK pada bidang keahlian Teknik Kendaraan Ringan (TKR). Langkah-langkah yang dilakukan oleh peneliti dalam mengembangkan buku ajar matematika berbasis matematika terapan menurut (Kristanto et al., 2018) sebagai berikut:

\section{Analysis}

Tahap awal yaitu analisis (Analysis), peneliti menganalisis buku ajar yang digunakan dalam pembelajaran melalui Buku Sekolah Elektronik (BSE) matematika kelas X, XI, dan XII didapatkan bahwa dalam buku ajar penggambaran materi masih dituliskan secara umum, belum terdapat penggambaran yang menyinggung bidang keahlian Teknik Kendaraan Ringan (TKR), sedangkan untuk buku matematika terapan, dari sepuluh buku yang telah dianalisis hanya terdapat 1 buku yang berisi materi Teknik Kendaraan Ringan (TKR). Selanjutnya peneliti melakukan wawancara kepada guru matematika, hasilnya menujukkan perlu adanya pengembangan buku ajar matematika berbasis matematika. Sesuai penelitian dari (Pratama \& Retnawati, 2018) bahwa buku ajar untuk diperhatikan karena sebagai sumber penting dalam belajar ketika membuat perencanaan dan melaksanakan pembelajaran di kelas. Kemudian peneliti memberikan angket seperti Tabel 4 yang terdiri dari 10 butir pertanyaan terkait analisis kebutuhan kepada 68 peserta didik kelas $\mathrm{X}$ bidang keahlian Teknik Kendaraan Ringan (TKR) untuk mengetahui kebutuhan peserta didik dalam penggunaan buku ajar pada proses pembelajaran matematika.

Tabel 4. Instrumen Analisis Kebutuhan Peserta Didik

\begin{tabular}{|c|l|c|c|}
\hline No & \multicolumn{1}{|c|}{ Indikator } & Butir Pertanyaan & Jumlah \\
\hline 1 & Ketersediaan Buku Ajar & 1,4 & 2 \\
\hline 2 & Manfaat Buku Penunjang & $3,5,6$ & 3 \\
\hline 3 & Kesulitan Belajar & 2,7 & 2 \\
\hline 4 & Kebutuhan Buku Ajar & $8,9,10$ & 3 \\
\hline \multicolumn{2}{|c|}{ Jumlah } & 10 \\
\hline
\end{tabular}


Hasil dari angket kebutuhan buku ajar menujukkan bahwa sebesar 93\% peserta didik membutuhkan alternatif buku ajar atau perangkat pembelajaran (Nur Arivina \& Jailani, 2020) yang dapat digunakan untuk membantu memahami materi trigonometri yang lebih menarik dan mudah dipahami. Selain itu, 95,5\% peserta didik setuju jika dikembangkan sebuah buku ajar matematika yang dihubungkan dengan materi jurusan Teknik Kendaraan Ringanb (TKR) untuk digunakan dalam proses pembelajaran (Armiati et al., 2019), sehingga materi trigonometri mudah dipahami.

\section{Design}

Tahap kedua adalah perancangan (Design), peneliti menentukan Kompetensi Dasar (KD), kemudian menyusun kerangka struktur materi Trigonometri dengan berbantuan buku paket matematika kelas X SMK. Buku ajar matematika pada materi Trigonometri ini berisi cover, Kompetensi Dasar (KD), pendahuluan, materi pembelajaran yang dihubungkan dengan teori-teori pada bidang keahlian Teknik Kendaraan Ringan (TKR), rangkuman, uji kompetensi diri, dan sumber. Selanjutnya yaitu pemilihan desain menarik yang akan digunakan dalam buku ajar matematika berbasis matematika terapan pada materi Trigonometri.

\section{Development, Implementation, dan Evaluation}

Tahap selanjutnya yaitu pengembangan (Development). Pada tahap ini dikembangkan buku ajar matematika berbasis matematika terapan pada materi Trigonometri yang dibuat dengan berbantuan buku matematika terapan. Setelah itu, dilakukan validasi buku ajar oleh ahli materi dan ahli media serta melakukan revisi produk (buku ajar) atas dasar saran dari para ahli (Gusnidar et al., 2018). Validasi oleh ahli materi mencakup indikator yaitu aspek isi materi, aspek bahasa, dan aspek kegunaan. Kemudian hasil rekapitulasi validasi oleh ahli materi diketahui bahwa rata-rata persentase tertinggi diperoleh pada aspek isi materi dengan persentase $95.5 \%$ berkategori sangat baik. Selain itu kedua aspek yang lainnya yaitu aspek bahasa dan aspek kegunaan masing- masing memperoleh persentase $86,5 \%$ dan 95\%, kedua aspek tersebut pun berkategori sangat baik.

Validasi oleh ahli media mencakup indikator yaitu aspek tampilan, aspek gambar, serta aspek kesesuaian dengan sasaran pengguna. Kemudian hasil rekapitulasi validasi oleh ahli media diketahui bahwa rata-rata persentase tertinggi diperoleh pada aspek tampilan yaitu dengan persentase $91 \%$ berkategori sangat baik. Selain itu kedua aspek yang lainnya yaitu aspek gambar dengan persentase 87,5\% berkategori sangat baik serta aspek kesesuaian dengan sasaran memperoleh persentase $80 \%$ berkategori baik. Berdasarkan rekapitulasi hasil validasi oleh para ahli dimana rata-rata persentase ahli materi diperoleh 92.5\% dan rata-rata persentase ahli media diperoleh $86,5 \%$. Hasil tersebut menujukkan bahwa buku ajar matematika berbasis matematika terapan pada materi Trigonometri untuk kelas X SMK layak untuk digunakan dengan perolehan kategori keduanya yaitu sangat baik 


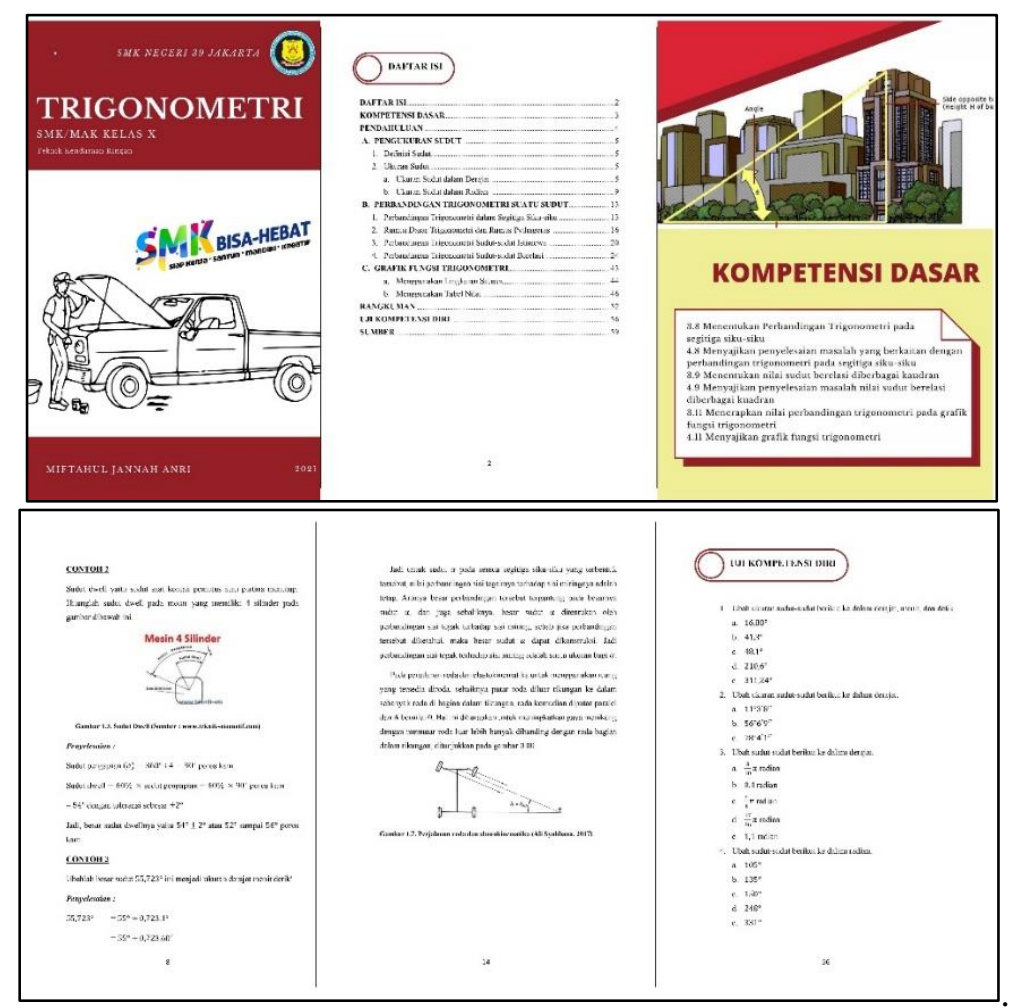

Gambar 2. Buku Ajar Matematika Berbasis Matematika Terapan

Tahap keempat adalah Implementasi (Implementation). Pada tahap ini dilakukan pengujian buku ajar matematika kepada guru dan peserta didik. Buku ajar matematika yang diujicobakan kepada guru mencakup indikator penilaian yaitu aspek penyajian materi, aspek bahasa, aspek tampilan, dan aspek kegunaan. Selain itu, buku ajar matematika yang diujicobakan kepada peserta didik mencakup indikator penilaian yaitu aspek ketertarikan, aspek isi materi, dan aspek bahasa. Pengujian buku ajar matematika ini terdiri dari uji coba skala kecil dan uji coba skala besar.

Pada uji coba skala kecil, buku ajar diujicobakan kepada dua orang guru matematika dan empat orang peserta didik kelas X Teknik Kendaraan Ringan (TKR) SMK Negeri 39 Jakarta. Rekapitulasi hasil respon guru matematika dapat diketahui bahwa rata-rata persentase tertinggi diperoleh aspek penyajian materi dengan persentase $91,5 \%$ berkategori sangat baik. Selain itu ketiga aspek yang lainnya yaitu aspek bahasa, aspek tampilan, dan aspek kegunaan masing-masing memperoleh persentase yaitu 87,5\%, 90\%, dan 88,5\% serta ketiga aspek tersebut pun berkategori sangat baik. Sedangkan rekapitulasi hasil respon peserta didik pada uji coba skala kecil dapat diketahui bahwa rata-rata persentase tertinggi diperoleh pada aspek ketertarikan dan aspek isi materi dengan masing-masing persentase $86 \%$ dan $86 \%$ keduanya berkategori sangat baik. Selain itu aspek yang lainnya yaitu aspek bahasa dan memperoleh persentase yaitu $84 \%$ berkategori sangat baik.

Pada uji coba skala besar, buku ajar matematika diujicobakan kepada 68 orang peserta didik di kelas X Teknik Kendaraan Ringan (TKR) SMK Negeri 39 Jakarta. Rekapitulasi hasil respon peserta didik pada uji coba skala besar dapat diketahui bahwa rata-rata persentase tertinggi diperoleh pada aspek bahasa 
dengan persentase $84 \%$ berkategori sangat baik. Selain itu kedua aspek yang lainnya yaitu aspek ketertarikan dan aspek isi materi masing-masing memperoleh persentase yaitu $83 \%$ dan $82 \%$ serta kedua aspek tersebut pun berkategori sangat baik. Kemudian rata-rata dari persentase keseluruhan pada uji coba skala besar ini yaitu sebesar $83 \%$ dengan kategori sangat baik. Selanjutnya, rekapitulasi hasil respon peserta didik menujukkan bahwa persentase keseluruhan pada uji coba skala kecil yaitu 85,5\% dan uji coba skala besar yaitu $83 \%$. Kedua pengujian tersebut menujukkan bahwa buku ajar matematika berbasis matematika terapan dikatakan efektif dengan kategori sangat baik.

Tahap kelima yaitu tahap evaluasi (evaluation), penelitian ini menghasilkan buku ajar pada materi Trigonometri yang pada penjelasan materinya dikaitkan dengan bidang keahlian Teknik Kendaraan Ringan (TKR) yang valid, layak, dan efektif. Namun disamping itu terdapat beberapa masukan dari para validator ahli yang dijelaskan pada Tabel 5 .

Tabel 5. Hasil Perbaikan Berdasarkan Saran dari Para Ahli

\begin{tabular}{|c|c|}
\hline Prototype Awal & Prototype Revisi \\
\hline $\begin{array}{l}\text { Ada referensi aplikasi dalam membuat } \\
\text { grafik Trigonomteri, mengingat } \\
\text { pembelajaran berbasis digital. }\end{array}$ & 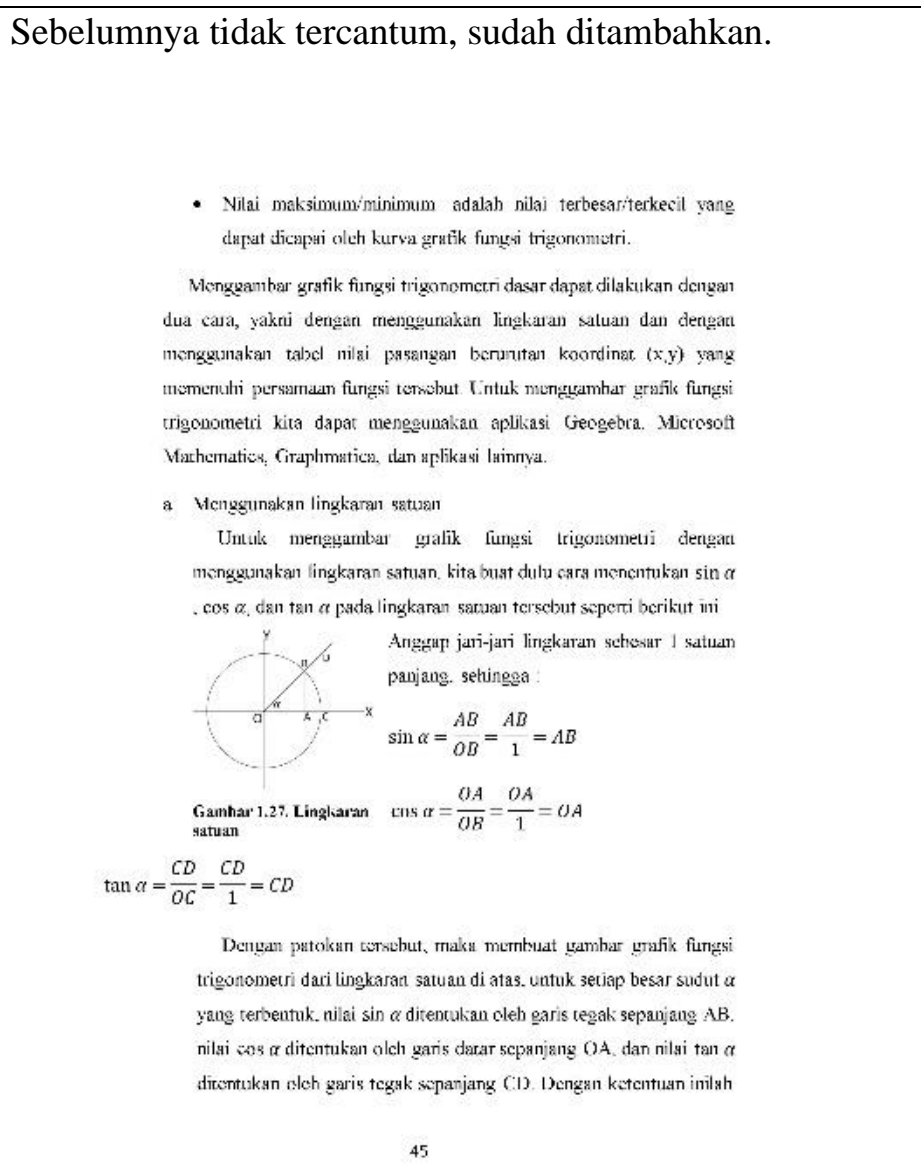 \\
\hline $\begin{array}{l}\text { Sebaiknya gambar disesuaikan dengan } \\
\text { proporsi dan berikan keterangan pada tiap } \\
\text { gambar }\end{array}$ & $\begin{array}{l}\text { Sebelumnya proporsi gambar sudah sesuai tetapi hanya } \\
\text { beberapa gambar yang diberikan keterangan, dan sudah } \\
\text { ditambahkan }\end{array}$ \\
\hline
\end{tabular}




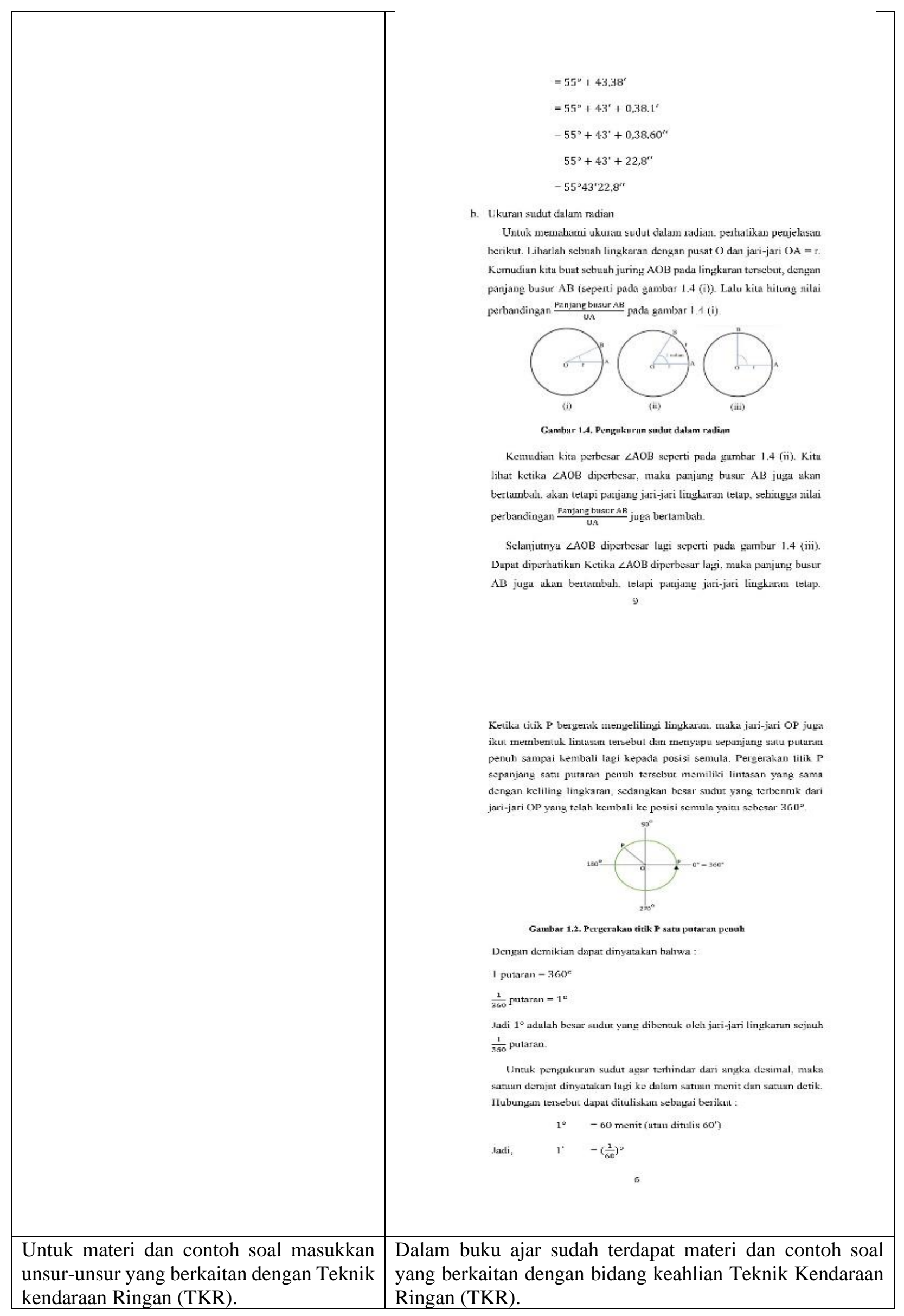




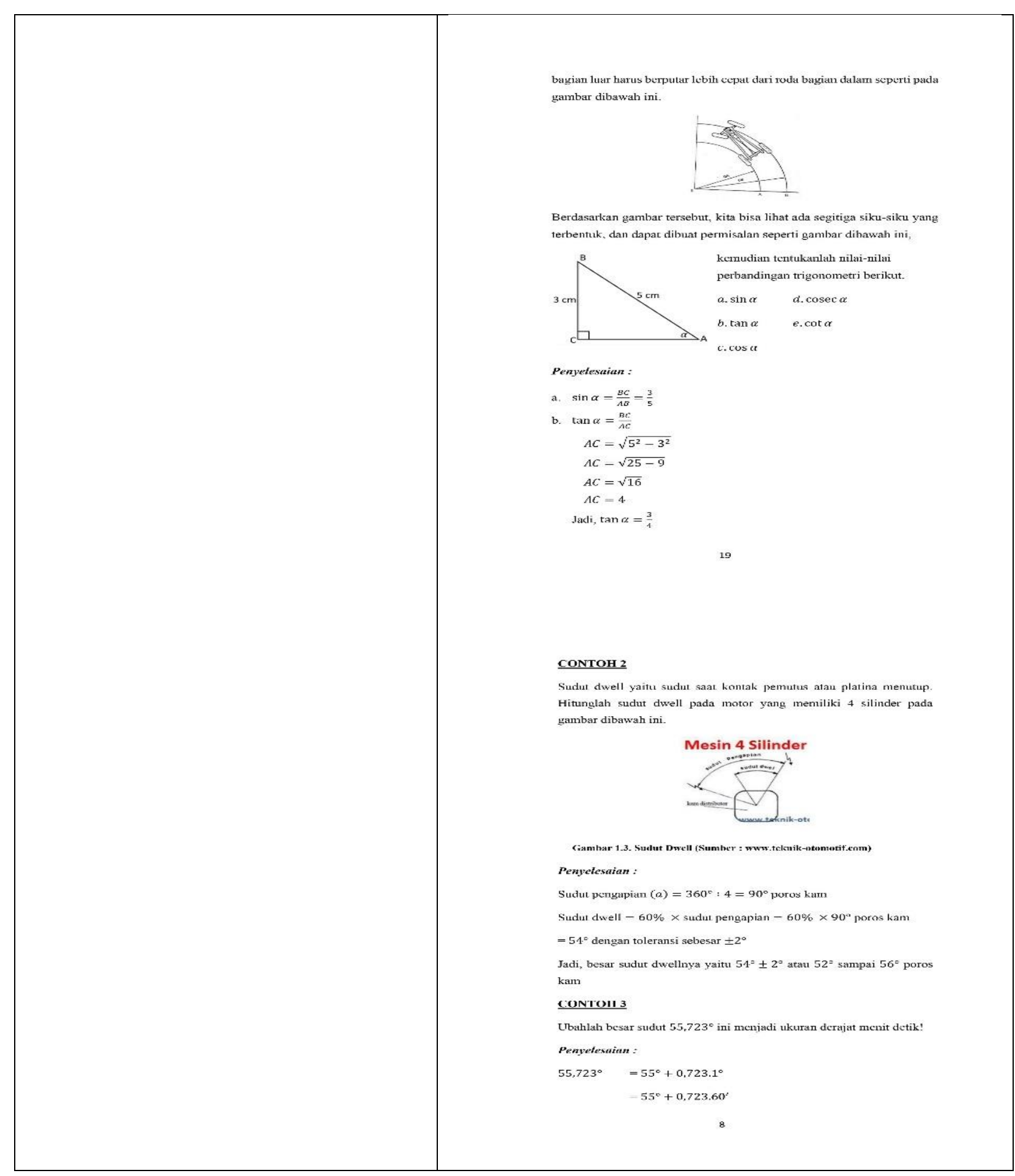

\section{KESIMPULAN}

Berdasarkan penelitian dan pengembangan buku ajar matematika berbasis matematika terapan pada materi Trigonometri untuk peserta didik SMK kelas X bidang keahlian Teknik Kendaraan Ringan (TKR), sebagai berikut: 1) Pada penelitian ini telah dikembangkan buku ajar matematika berbasis matematika terapan pada materi Trigonometri menggunakan model ADDIE, dikembangkan melalui beberapa tahap diantaranya analysis (analisis) tahap ini peneliti mencari informasi kebutuhan pembelajaran kepada peserta didik; Design (Perancangan) peneliti menentukan buku ajar dan merancang produk awal; Development 
(pengembangan) tahap ini peneliti melakukan validasi terhadap produk awal serta uji coba skala kecil dan uji coba skala besar untuk mendapatkan revisi dan menghasilkan produk final; Implementation (Penerapan) tahap ini penerapan produk untuk mengetahui keefektifan buku ajar; dan evaluation (evaluasi) tahap ini menghasilkan produk yang sudah diperbaiki dari para validator. 2) Validasi buku ajar matematika berbasis matematika terapan pada materi trigonometri oleh ahli materi memperoleh penilaian kategori sangat baik dengan persentase $92,5 \%$ dan oleh ahli media memperoleh penilian kategori sangat baik dengan persentase 86,5\% . 3) Efektifitas buku ajar matematika berbasis matematika terapan pada materi Trigonometri dengan uji coba skala kecil memperoleh persentase 85,5\% masuk dalam kategori sangat baik dan uji coba skala besar memperoleh persentase $83 \%$ masuk dalam kategori sangat baik.

\section{REFERENSI}

Akbar, R. R. A., \& Komarudin. (2018). Pengembangan Video Pembelajaran Matematika Berbantuan Media Sosial Instagram sebagai Alternatif Pembelajaran. Desimal: Jurnal Matematika, 1(2), 209-215. https://doi.org/10.24042/djm.v1i2.2343

Amirullah, G., \& Susilo, S. (2018). Pengembangan Media Pembelajaran Interaktif Pada Konsep Monera Berbasis Smartphone Android. WACANA AKADEMIKA: Majalah Ilmiah Kependidikan, 2(1), 38-47. https://doi.org/10.30738/wa.v2i1.2555

Arif Z, M. A., \& Abdillah, A. (2018). Pengembangan Modul Belajar Mandiri LaTeX Beamer Sebagai Alternatif Media Presentasi Mahasiswa Program Studi Pendidikan Matematika. JTAM| Jurnal Teori Dan Aplikasi Matematika, 2(2), 138-143. https://doi.org/10.31764/jtam.v2i2.716

Armiati, Yerizon, \& Niscaya, R. (2019). Flipped classroom based mathematics learning equipment for students in grade X SMA. Journal of Physics: Conference Series, 1317(1), 1-11. https://doi.org/10.1088/1742-6596/1317/1/012129

Bernard, M., Sumarna, A., Rolina, R., \& Akbar, P. (2019). Development of high school student work sheets using VBA for microsoft word trigonometry materials. Journal of Physics: Conference Series, 1315(1), 1-9. https://doi.org/10.1088/1742-6596/1315/1/012031

Gusnidar, Sutrisno, \& Syaiful. (2018). Pengembangan Perangkat Pembelajaran Matematika Berdasarkan Kerangka Kerja Tpack Untuk Mengoptimalkan Kemampuan Penalaran Deduktif. AKSIOMA, Jurnal Pendidikan Matematika FKIP Universitas Muhammadiyah Metro, 7(3), 403-412. https://doi.org/http://dx.doi.org/10.24127/ajpm.v7i3.1557

Hassani, S. (2009). Mathematical Methods for Students of Physics and Related Fields. In Journal of Chemical Information and Modeling.

Hine, G. S. C. (2015). Strengthening Pre-service Teachers' Mathematical Content Knowledge. Journal of University Teaching and Learning Practice, 12(4), 1-11.

Kristanto, A., Mustaji, Mariono, A., Sulistiowati, \& Nuryati, D. W. (2018). Developing Media Module Proposed to Editor in Editorial Division. Journal of Physics: Conference Series, 947(1), 1-7. https://doi.org/10.1088/1742-6596/947/1/012054 
Nur'aini, I. L., Harahap, E., Badruzzaman, F. H., \& Darmawan, D. (2017). Pembelajaran Matematika Geometri Secara Realistis Dengan GeoGebra. Matematika, 16(2), 1-6. https://doi.org/10.29313/jmtm.v16i2.3900

Nur Arivina, A., \& Jailani. (2020). Development of trigonometry learning kit with a STEM approach to improve problem-solving skills and learning achievement. Jurnal Riset Pendidikan Matematika, 7(2), 178-194. http://journal.uny.ac.id/index.php/jrpmhttps://doi.org/10.21831/jrpm.v7i2.35063

Ojose, B. (2011). Mathematics literacy: are we able to put the mathematics we learn into everyday use? Journal of Mathematics Education, 4(1), 89-100.

Pratama, G. S., \& Retnawati, H. (2018). Urgency of Higher Order Thinking Skills (HOTS) Content Analysis in Mathematics Textbook. Journal of Physics: Conference Series, 1097(1), 1-8. https://doi.org/10.1088/1742-6596/1097/1/012147

Sugiyono. (2019). Metode Penelitian \& Pengembangan Research and Development.

Sujana, I. W. C. (2019). Fungsi Dan Tujuan Pendidikan Indonesia. Adi Widya: Jurnal Pendidikan Dasar, 4(1), 29-39. https://doi.org/10.25078/aw.v4i1.927

Tegeh, I., Jampel, I., \& Pudjawan, K. (2014). Model Penelitian Pengembangan. Graha Ilmu.

Wijaya, T. T., Ying, Z., \& Cunhua, L. (2020). Using Vba Learning Media To Improve Students' Mathematical Understanding Ability. Journal On Education, 02(02), 245-254. https://doi.org/https://doi.org/10.31004/joe.v2i3.314

Wijaya, T. T., Ying, Z., \& Purnama, A. (2020). Using Hawgent dynamic mathematics software in teaching trigonometry. International Journal of Emerging Technologies in Learning, 15(10), 215-222. https://doi.org/10.3991/ijet.v15i10.13099. 